\title{
Purification and Characterization of a Lectin from Bulbs of Cyclamen Mirabile
}

\section{Cyclamen Mirabile Soğanından Lektin Saflaştırılması ve Karakterizasyonu}

\author{
Ebru Kocadă̆ Kocazorbaz ${ }^{1 *}$, Ayşe Yağmur Azbazdar², Merve Aliakar Öztürk \\ Esra Menfaatli ${ }^{4}$ \\ Geliș / Received: 06/02/2020 \\ Revize / Revised: 12/08/2020 \\ Kabul / Accepted: 23/08/2020

\begin{abstract}
Lectin from the bulbs of Cyclamen mirabile which is an endemic species of Turkey was successfully isolated by affinity precipitation with alginate in one step. The purified protein produced two bands showing a dimeric structure in SDS-PAGE (13.5 and $14.8 \mathrm{kDa})$. C. mirabile lectin showed activity and stability in a broad $\mathrm{pH}$ scale and kept its haemagglutination activity in the temperature range of $4-40^{\circ} \mathrm{C} . \mathrm{MgCl}_{2}$ and $\mathrm{HgCl}_{2}$ inhibited the haemagglutination activity of the lectin. In this study, a practical and efficient purification procedure was carried out for $C$. mirabile lectin by using affinity precipitation with alginate.
\end{abstract}

Keywords- Lectin, Protein Purification, Cyclamen Mirabile

\section{$\ddot{\text { öz }}$}

Bu çalışmada, Türkiye'nin endemik bir türü olan Cyclamen mirabile soğanından tek adımda lektin saflaştırıldı. Yöntem olarak, amonyum sülfat ve ardından kalsiyum aljinat presipitasyonu kullanıldı. Saflaştırılan lektin SDS PAGE ile analiz edildiğinde 13.5 ve $14.8 \mathrm{kDa}$ molekül kütlelerine sahip iki protein bandı gözlendi. Hemaglütinasyon inhibisyon yöntemi ile $C$. mirabile soğanından elde edilen lektinin mannoz spesifik lektin olduğu belirlendi. C. mirabile lektini geniş bir $\mathrm{pH}$ aralığında ve $4-40^{\circ} \mathrm{C}$ arasında hemaglütinasyon aktivitesini korudu. $\mathrm{MgCl}_{2}$ ve $\mathrm{HgCl}_{2}$ metallerinin lektinin hemaglütinasyon aktivitesini inhibe ettiği görüldü.

Anahtar Kelimeler- Lektin, Protein Saflaştırma, Cyclamen Mirabile

\footnotetext{
1*Sorumlu yazar iletişim: ebru.kocadag.kocazorbaz@ege.edu.tr (https://orcid.org/0000-0001-5611-5235) Faculty of Science, Biochemistry Department, Ege University, Izmir

2illetişim: yagmur.azbazdar@gmail.com (https://orcid.org/0000-0003-0806-1003)

Izmir International Biomedicine and Genome Institute, 9 Eylul University, Izmir

3̇letişim: merve.aliakar@gmail.com (https://orcid.org/0000-0002-5897-4049)

Faculty of Science, Biochemistry Department, Ege University, Izmir

4İletişim: esramenfaatli@hotmail.com (https://orcid.org/0000-0002-2370-6415)

Faculty of Science, Biochemistry Department, Ege University, Izmir
} 


\section{INTRODUCTION}

Lectins are naturally found proteins that can bind carbohydrates with characteristic specificities. Lectins are significant proteins for unraveling biological processes and enlightening of protein and carbohydrate structures [1]. The first identified plant lectin was named ricin which was purified from the castor beans. The term of hemagglutinin arose after the discovery of the agglutination of red blood cells by ricin. Next, it was found that some hemagglutinins can agglutinate selectively human erythrocytes according to their $\mathrm{ABO}$ blood group type [2]. Lectin molecule has carbohydrate-binding sites more than two which led to attaching sugars on the surface of the cell causing cross-linking of cells and subsequent precipitation. Lectins appear in most organisms, such as viruses, bacteria, animals, and plants [3]. Mannose-specific lectins prevail among higher plants and defense the plants by recognizing the high-mannose-type glycans of plant predators or pathogens $[4,5]$. Lectins are precious tools for glycobiology and biomedical research and can be used as diagnostic probes, antitumor cytotoxins, tumorspecific surface markers, immunotoxins, and adhesion molecules. Many human pathogens initiate infection by using the cell surface glycans as either receptors or ligands [6-10]. Mostly, affinity chromatography is used to purify lectins besides recombinant DNA techniques [3]. In this study, a plant lectin was purified by using a simple affinity technique from Cyclamen mirabile, which is an endemic species of Turkey.

\section{MATERIALS AND METHODS}

\section{A. Materials}

Coomassie brilliant blue G250 (Fluka, Buchs, Switzerland), ammonium sulfate, bovine serum albumin, molecular weight marker (14-66 kDa), D-glucuronic acid, fructose, glucose, sucrose, galactose, mannose, N-acetyl D-glucosamine, lactose, D-galacturonic acid, D-galactosamine hydrochloride, D(-) lyxose, sodium alginate, sulphuric acid, phenol (Sigma Chemical Co.,St. Louis, Mo., U.S.A). Sheep blood was collected from the waste of the local abattoir.

\section{B. Preparation of Crude Extract with Ammonium Sulfate Precipitation}

$200 \mathrm{~g}$ of C. mirabile bulbs were peeled, cut into small pieces, and homogenized in $400 \mathrm{~mL} 25 \%$ ammonium sulfate using a blender. The crude extract was filtered from cheesecloth and centrifuged for $30 \mathrm{~min}$ at $9000 \mathrm{~g}$. The supernatant was precipitated by $70 \%$ ammonium sulfate and left overnight under the stirring condition for complete precipitation. The pellet was centrifuged at $9000 \mathrm{~g}$ for $30 \mathrm{~min}$ and dissolved in deionized water. Dialysis performed against deionized water to remove ammonium sulfate and the precipitate was kept at $-80^{\circ} \mathrm{C}$ until further use.

\section{Protein and Carbohydrate Analysis}

Bradford assay was used to estimate the protein concentrations with some modifications. As the standard known concentrations of bovine serum albumin were used [11]. Phenol sulphuric acid method was used to estimate total carbohydrate content, with dilutions of a known concentration of D-glucose [12].

\section{Affinity Precipitation of Lectin with Alginate}

$50 \mathrm{mM}$ of sodium acetate buffer at $\mathrm{pH} 4.5$ was used to prepare alginate solution $(2 \% \mathrm{v} / \mathrm{v})$. Necessary dilutions were made before use. The $C$. mirabile lectin was mixed with $0.5 \mathrm{~mL}$ of alginate solution and made up to $5.0 \mathrm{~mL}$ with acetate buffer. The lectin-alginate complex was precipitated with the addition of $0.4 \mathrm{~mL}$ of $1 \mathrm{M}$ $\mathrm{CaCl}_{2}$ solution and incubated for $20 \mathrm{~min}$ at $25^{\circ} \mathrm{C}$. The suspension was centrifuged for $10 \mathrm{~min}$ at $9000 \mathrm{~g}$. The precipitate was washed using $\mathrm{pH} 7.4100 \mathrm{mM}$ phosphate buffer containing $0.074 \mathrm{M} \mathrm{CaCl}_{2}$ [13]. $3 \mathrm{~mL}$ of acetate buffer was used for dissolving the lectin-alginate complex, containing $1 \mathrm{M}$ mannose, and incubated at $4^{\circ} \mathrm{C}$ for $18 \mathrm{~h}$. The alginate was precipitated and the eluate was dialyzed against distilled water $\left(24 \mathrm{~h}\right.$ at $\left.4^{\circ} \mathrm{C}\right)$. The eluate was checked for lectin activity.

\section{E. Haemagglutinating Activity}

Haemagglutination activity (HA) was measured in a U bottom microtiter plate according to Sureshkumar and Priya, using erythrocytes from sheep blood [14]. The definition of the haemagglutination unit (titer) was the highest dilution of the sample showing haemagglutination. 


\begin{tabular}{|c|c|c|}
\hline & $\begin{array}{l}\text { BŞEÜ Fen Bilimleri Dergisi } \\
8(1), 1-7,2021\end{array}$ & $\begin{array}{r}\text { BSEU Journal of Science } \\
\text { https://doi.org/10.35193/bseufbd.685652 }\end{array}$ \\
\hline $\begin{array}{l}\text { BILECIK SEYY EDEBALL } \\
\text { ONIVERSITESI }\end{array}$ & & 2458-7575 (https://dergipark.org.tr/tr/pub/bseufbd) \\
\hline
\end{tabular}

\section{F. Haemagglutination-Inhibition Assay}

Agglutination of the sheep red blood cells by the C.mirabile lectin was estimated according to Peng [15]. The sugar inhibition assay was performed using different concentrations of sugars such as fructose, sucrose, glucose, D-glucuronic acid, galactose, mannose, lactose, D-galacturonic acid, D-galactosamine hydrochloride, Nacetyl D-glucosamine, and $\mathrm{D}(-)$ lyxose.

\section{G. pH Effect on Haemagglutination Activity and Stability}

The effect of $\mathrm{pH}$ on the activity of the C.mirabile lectin was investigated by incubating the lectin in the stated buffers of $0.05 \mathrm{M}$ at different $\mathrm{pH}$ values: glycine- $\mathrm{HCl}$ ( $\mathrm{pH}$ 2.0-3.0), sodium acetate-acetic acid (pH 4.0-5.0), potassium phosphate $(\mathrm{pH} 6.0-7.0)$, Tris- $\mathrm{HCl}(\mathrm{pH} 8.0-9.0)$, sodium carbonate $(\mathrm{pH} \mathrm{10.0-11.0)} \mathrm{at} \mathrm{room} \mathrm{temperature}$ for $24 \mathrm{~h}$. The agglutination titer of the lectin in PBS was used as the control [16].

\section{H. Temperature Effect on Haemagglutination Activity and Stability}

The effect of temperature on the lectin activity was investigated with the standard assay procedure with PBS as the control within a temperature range from 4 to $60^{\circ} \mathrm{C}$. Thermostability was monitored by incubation of crude extract at ph 7.4 at temperatures ranging from $4-60^{\circ} \mathrm{C}$ for $30 \mathrm{~min}$ and the relative lectin activities were assayed with the standard assay conditions.

\section{Effect of Metal Ions}

The C. mirabile lectin $(50 \mu \mathrm{L})$ was incubated for $24 \mathrm{~h}$ with metal ions $\left(\mathrm{Mg}^{2+}, \mathrm{Ba}^{2+}, \mathrm{Ni}^{2+}, \mathrm{Hg}^{2+}, \mathrm{Na}^{+}\right.$and $\left.\mathrm{Ca}^{2+}\right)$ at various concentrations with constant shaking. After that, each sample was mixed with $50 \mu \mathrm{L}$ of erythrocyte suspension $(2 \% \mathrm{v} / \mathrm{v})$ and the hemagglutination activities were measured.

\section{J. SDS PAGE Analysis}

Sodium dodecyl sulfate-polyacrylamide gel electrophoresis (SDS PAGE) was carried out using the discontinuous buffer system described by Laemmli using a 4-12\% mini gel [17]. After electrophoresis, the gel was stained with Coomassie brilliant blue in 10\% acetic acid for one hour and destained with distilled water by heating in a microwave oven in short periods and replacing of distilled water until protein bands are clearly defined.

\section{RESULTS AND DISCUSSIONS}

\section{A. Purification of C. mirabile Lectin}

The C. mirabile lectin was purified by affinity precipitation with alginate and separated on $12 \%$ polyacrylamide gel. Figure 1 reveals that $C$. mirabile lectin is a dimeric protein, two proteins with molecular sizes of 13.5 and $14.8 \mathrm{kDa}$.

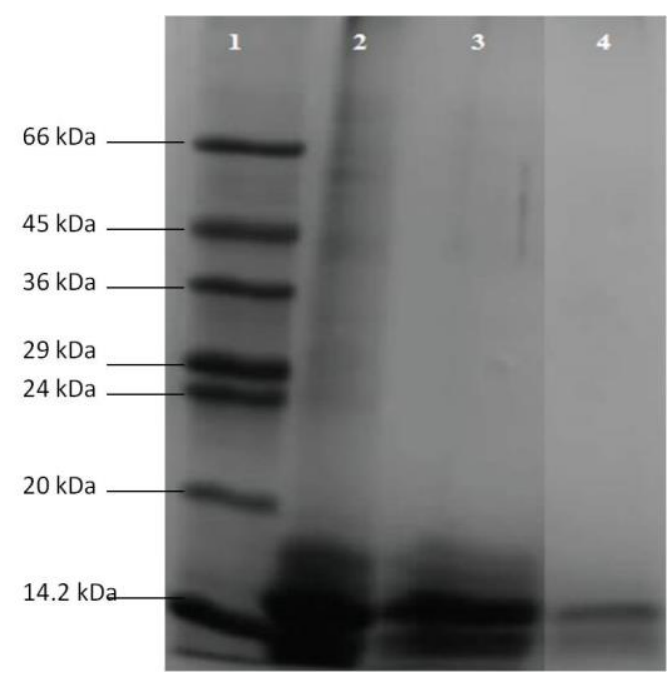

Figure 1. SDS PAGE gel image. Protein standards (1), Crude extract (2), 70\% Supernatant (3), Purified lectin (4) 


\begin{tabular}{|c|c|c|}
\hline & $\begin{array}{l}\text { BŞEÜ Fen Bilimleri Dergisi } \\
8(1), 1-7,2021\end{array}$ & $\begin{array}{r}\text { BSEU Journal of Science } \\
\text { https://doi.org/10.35193/bseufbd.685652 }\end{array}$ \\
\hline $\begin{array}{l}\text { BILECIK SEYY EDEBALL } \\
\text { ONIVERSITESI }\end{array}$ & & 2458-7575 (https://dergipark.org.tr/tr/pub/bseufbd) \\
\hline
\end{tabular}

\section{B. Protein, Carbohydrate and Haemagglutination Units for Lectin}

Protein concentration, carbohydrate content, and agglutination activity for each step of purification were shown in Table 1. Specific activity increased with purification steps. Pure lectin had the most specific activity.

Table 1. Protein concentration, carbohydrate content and agglutinate activity

\begin{tabular}{|c|c|c|c|c|c|c|}
\hline & $\begin{array}{l}\text { Volume } \\
(\mathbf{m L})\end{array}$ & $\begin{array}{l}\text { Protein }(\mathbf{m g} \\
\left.\mathrm{mL}^{-1}\right)\end{array}$ & $\begin{array}{l}\text { Total Protein } \\
(\mathbf{m g})\end{array}$ & $\begin{array}{c}\text { Activity } \\
\text { (HAU) }\end{array}$ & $\begin{array}{c}\text { Spesific Activity (HAU mg-1 } \\
\text { protein) }\end{array}$ & $\begin{array}{c}\text { Carbohydr } \\
\text { ate } \\
(\mathrm{mg})\end{array}$ \\
\hline Homogenate & 470 & 0.132 & 62.04 & 1024 & 16.51 & 3236 \\
\hline $\begin{array}{l}25 \% \\
\text { Supernatant }\end{array}$ & 460 & 0.038 & 17.48 & 256 & 14.65 & - \\
\hline $25 \%$ Pellet & 9 & 1.279 & 11.51 & 2048 & 117.93 & 113.9 \\
\hline $\begin{array}{l}70 \% \\
\text { Supernatant }\end{array}$ & 450 & 0.015 & 6.75 & 16 & 2.37 & - \\
\hline $70 \%$ Pellet & 32 & 0.453 & 14.5 & 16384 & 1130 & 719.36 \\
\hline Pure Lectin & 1.5 & 15 & 0.0225 & 128 & 5688 & - \\
\hline
\end{tabular}

\section{C. pH Effect on Haemagglutination Activity and Stability}

The purified lectin was able to maintain its stability in a wide $\mathrm{pH}$ range which is between $\mathrm{pH} 5.0$ and 11.0 (Figure 2). The optimum $\mathrm{pH}$ for purified C.mirabile lectin to agglutinate sheep blood erythrocytes was 5.0-8.0 (Figure 3). Agglutination capacity decreased below pH 5.0 and above $\mathrm{pH} 9.0$.

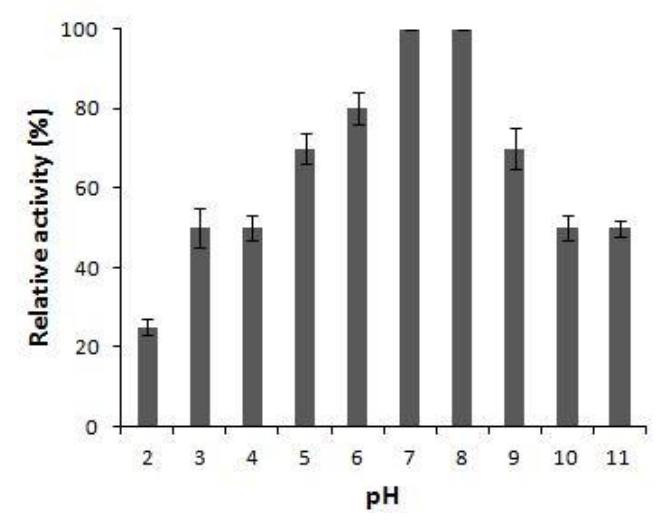

Figure 2. Alteration of lectin haemagglutination stability depending on $\mathrm{pH}$

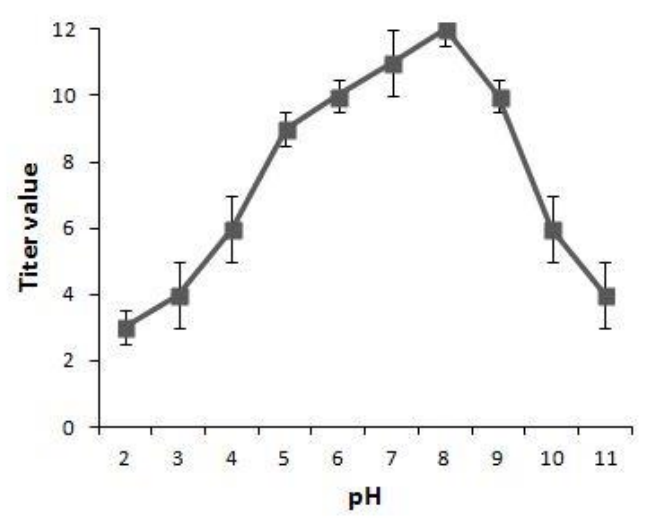

Figure 3. Alteration of lectin haemagglutination activity depending on $\mathrm{pH}$ 


\section{Temperature Effect on Haemagglutination Activity and Stability}

Agglutination stability was studied within the temperature range of $0-60^{\circ} \mathrm{C}$ for pure lectin which is most stable at $37^{\circ} \mathrm{C}$ and $40^{\circ} \mathrm{C}$. The results are shown in Figure 4. Purified C. mirabile lectin retained the full agglutinating activity in the temperature range of $4-40^{\circ} \mathrm{C}$, but there was a dramatic decrease between 40 and $55^{\circ} \mathrm{C}$, and at $55^{\circ} \mathrm{C}$ the activity was completely abolished showing thermal inactivation. The results are shown in Figure 5.

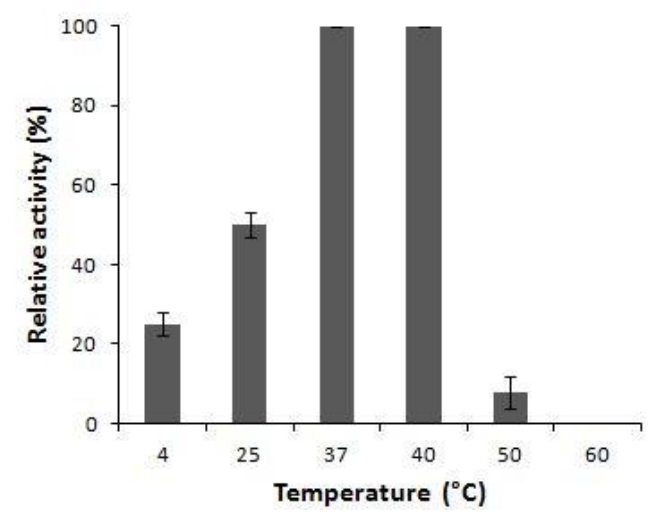

Figure 4. Alteration of lectin stability depending on temperature

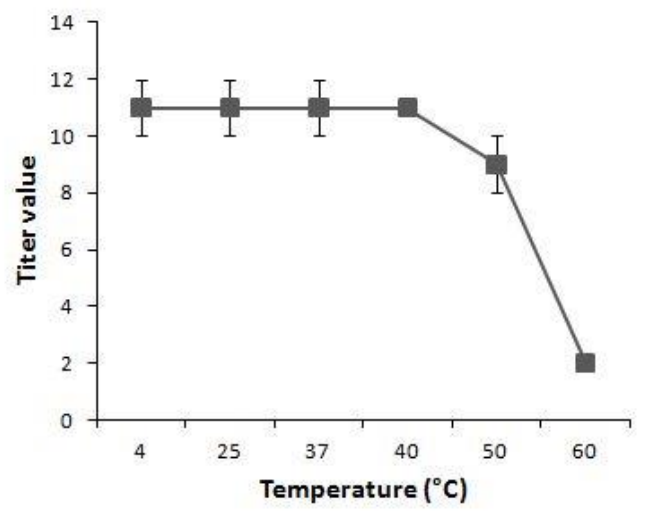

Figure 5. Alteration of lectin haemagglutination activity depending on temperature

\section{E. Haemagglutination-Inhibition Assay}

Fructose, glucose, galactose, mannose, lactose, sucrose, D-galactosamine hydrochloride, N-acetyl glucosamine, D-galacturonic acid, D(-)lyxose, and D-glucuronic acid used for haemagglutination-inhibition assay of purified $C$. mirabile lectin to agglutinate sheep erythrocytes. Lectin bound mannose with the most affinity, indicating that purified lectin is mannose-specific. The results are shown in Table 2. 


\begin{tabular}{|c|c|c|}
\hline & $\begin{array}{l}\text { BŞEÜ Fen Bilimleri Dergisi } \\
8(1), 1-7,2021\end{array}$ & $\begin{array}{r}\text { BSEU Journal of Science } \\
\text { https://doi.org/10.35193/bseufbd.685652 }\end{array}$ \\
\hline ERSI & & 2458-7575 (https://dergipark.org.tr/tr/pub/bseufbd) \\
\hline
\end{tabular}

Table 2. The sugar inhibition assay for pure lectin

\begin{tabular}{ll}
\hline Carbohydrate & $\mathbf{m M}$ \\
\hline Mannose & 0.156 \\
D-galacturonic acid & 0.625 \\
Lactose & 1.2500 \\
D(-) lyxose & $2.500 \mathrm{~m}$ \\
Glucose & - \\
N-Acetyl-D-Glucosamine & - \\
Xylose & - \\
Galactose & - \\
Sucrose & - \\
Fructose & - \\
D-Galactosamine hydrochloride & - \\
D-Glucuronic acid & - \\
\hline
\end{tabular}

\section{F. Inhibition of Hemagglutination by Metal Ions}

Various metal ions were used to investigate the effect of metal ions on the hemagglutination activity. Results showed that lectin has the most affinity for magnesium and mercury while giving negative results for other metal ions (Table 3).

Table 3. Lectin affinity for metal ions

\begin{tabular}{ll}
\hline Metal ion & Concentration $(\mathbf{m M})$ \\
\hline $\mathrm{CaCl}_{2}$ & - \\
$\mathrm{NaCl}$ & - \\
$\mathrm{HgCl}_{2}$ & 5.0 \\
$\mathrm{Ni}(\mathrm{II})$ & - \\
$\mathrm{MgCl}_{2}$ & 2.5 \\
$\mathrm{BaCl}_{2}$ & - \\
\hline
\end{tabular}

\section{CONCLUSION}

A mannose-specific, dimeric C. mirabile lectin with the molecular weights of 13.5 and $14.8 \mathrm{kDa}$ was isolated by affinity precipitation with alginate. Haemagglutination activity of the crude extract increased with purification steps and purified lectin maintained its activity and stability in a broad $\mathrm{pH}$ scale. Nevertheless, it showed maximum activity at $\mathrm{pH}$ 8. Although haemagglutination activity and lectin stability were observed between $4-40^{\circ} \mathrm{C}$, there was a drastic decrease with ascending temperature. Also, it was seen that only mercury and magnesium were able to inhibit haemagglutination activity among other metal ions. Purified lectin showed the most affinity to mannose among other sugars which reveals $C$. mirabile lectin is a mannose-specific lectin. In this study, the $C$. mirabile lectin was purified and characterized for the first time. Further work will be necessary to study the bioactivity of lectin, such as anticancer and antimicrobial activity. 


\section{REFERENCES}

[1] Kennedy, J.F., Palva, P.M.G., Corella, M.T.S., Cavalcanti, M.S.M. \& Coelho, L.C.B.B. (1995). Lectins, versatile proteins of recognition: a review. Carbohyd Polym, 26, 219-230.

[2] Vandenborre, G., Smagghe, G. \& Van Damme, E.J.M. (2011). Plant lectins as defense proteins against phytophagous insects. Phytochemistry, 72, 1538-1550.

[3] Lis, H. \& Sharon, N. (1998). Lectins: carbohydrate-specific proteins that mediate cellular recognition. Chemical Reviews, 98(2), 637-674.

[4] Barre, A., Bourne, Y., Van Damme, E.J.M., Peumans, W.J. \& Rougé, P. (2001). Mannose-binding plant lectins: different structural scaffolds for a common sugar-recognition process. Biochimie, 83(7), 645-651.

[5] Luo, Y., Xu, X., Liu, J., Li, J., Sun, Y., Liu, Z., Liu, J., Van Damme, E., Balzarini, J. \& Bao, J. (2007). A novel mannose-binding tuber lectin from Typhonium divaricatum (L.) Decne (family Araceae) with antiviral activity against HSV-II and anti-proliferative effect on human cancer cell lines. J Biochem Mol Biol, 40(3), 358-367.

[6] Dhuna, V., Bains, J. S., Kamboj, S. S., Singh, J., Kamboj, S. \& Saxena, A. K. (2005). Purification and characterization of a lectin from Arisaema tortuosum Schott having in-vitro anticancer activity against human cancer cell lines. J Biochem Mol Biol, 38(5), 526-32.

[7] Paiva, P. M. G., Gomes, F. S., Napoleão, T. H., Sá, R. A., Correia, M. T. S., \& Coelho, L. C. B. B. (2010). Antimicrobial activity of secondary metabolites and lectins from plants. Current Research, Technology and Education Topics in Applied Microbiology and Microbial Biotechnology, 2, 396-400.

[8] Nunes, E. S., Souza, M. A. A., Vaz, A. F. M., Santana, G. M. S., Gomes, F. S., Coelho, L. C. B. B., Paiva, P.M.G., Silva, R. M. L., Silva-Lucca, R. A., Oliva, M. L. V., Guarnieri, M. C. \& Correia, M.T.S. (2011). Purification of a lectin with antibacterial activity from Bothrops leucurus snake venom. Comp Biochem Physiol B, 159, 57-63.

[9] Hamid, R., Masood, A., Wani, I. H., \& Rafiq, S. (2013). Lectins: proteins with diverse applications. Journal of Applied Pharmaceutical Science, 3(4), 93-103.

[10] Dias, R. O., Machado, L. S., Migliolo, L. \& Franco, O. L. (2015). Insights into animal and plant lectins with antimicrobial activities. Molecules, 20(1), 519-541.

[11] Bradford, M. (1976). A rapid and sensitive method for the quantitation of microgram quantities of protein utilizing the principle of protein dye binding. Anal Biochem, 72, 248-254.

[12] DuBois, M., Gilles, K. A., Hamilton, J. K., Rebers, P. A. \& Smith, F. (1956). Colorimetric method for determination of sugars and related substances. Analytical Chemistry, 28(3), 350-356.

[13] Teotia, S., Lata, R., Khare, S. K. \& Gupta, M. N. (2001). One-step purification of glucoamylase by affinity precipitation with alginate. Journal of molecular recognition, 14(5), 295-299.

[14] Sureshkumar, T. \& Priya, S. (2012). Purification of a lectin from M. rubra leaves using immobilized metal ion affinity chromatography and its characterization. Applied biochemistry and biotechnology, 168(8), 22572267.

[15] Lin, P., Ye, X. \& Ng, T. B. (2008). Purification of melibiose-binding lectins from two cultivars of Chinese black soybeans. Acta biochimica et biophysica Sinica, 40(12), 1029-1038.

[16] Mojica, E.R.E. \& Merce, F.E. (2005). Isolation and partial characterization of a lectin from the internal organs of sea cucumber (Holothuria scabra jaeger). Int J Zool Res, 1, 59-65.

[17] Laemmli, U.K. (1970). Cleavage of structural proteins during the assembly of the head of bacteriophage T4. Nature, 227, 680-685. 